Towards an activist approach to research and advocacy for girls and physical education

Kimberly L. Oliver, $\mathrm{PhD}$ (Corresponding author)

Professor

Physical Education Program Director

Department of Human Performance, Dance and Recreation

P.O. Box 30001 MSC 3M

New Mexico State University

Las Cruces, NM 88003

David Kirk PhD

Alexander Chair in Physical Education and Sport

Institute for Sport and Physical Activity Research

University of Bedfordshire

Polhill Avenue

Bedford MK41 9EA 


\title{
Towards an activist approach to research and advocacy for girls and physical education
}

\begin{abstract}
Background: Much research and practice in the field of physical activity and physical education for girls has been trapped in a reproductive cycle of telling the 'same old story' as if it is news over and over again, since at least the 1980s. A thread running through this narrative is that despite all of this research and related interventions, we have yet to find the 'solution' to the 'problem' of girls and physical education. As a result, there appears to have been made little progress in terms of changing things for the better for the majority of girls. Purpose: We offer an activist approach to work with girls in physical education as one possible means of breaking the reproductive cycle of research and media reporting that we suggest has worked against improving the situation for girls. We take a pragmatist stance to ask 'can we make the situation for girls better than it is currently?' and 'how might we go about this task?' We propose an activist approach not as 'the solution' to the 'problem' of girls in physical education, but as one worthy of testing in practice.
\end{abstract}

Process: We begin by outlining the broad features of an activist approach to the working with girls in physical education. We then overview the findings of a growing body of activist studies in physical education and identify four critical elements that we believe need to be present in order to assist girls to identify, name and negotiate barriers to their engagements with physical education and their participation in physically active lifestyles. We highlight one example of an activist study that shows how the four critical elements interact in their work with girls.

Discussion: We argue for the need for a consensus around improving the current situation of girls in physical education, for a scaling-up of this activist work as it is tested in practice, and for the coincidental development of a pedagogical model for working with girls in physical education.

\section{Introduction}

Little progress appears to have been made to changing the situation for girls in school physical education for at least the past 40 years. Reports appear regularly in the media and in the research literature that suggests girls are 'the problem' (Vertinsky, 1992; Garrett 2004). The narrative holds that girls' attitudes lead them by early adolescence to disengage from 
physical education and drop out of physical activity (Biddle et al. 2005). These reports more recently have begun to highlight the potential negative consequences for girls' health and well-being, and to frame this problem within the context of an obesity epidemic (BarrAnderson et al. 2008). The situation of girls' declining physical activity levels has persisted despite some sophisticated theorization of the topic of gender and sport and repeated calls for action in physical education (Flintoff and Scraton 2006). It has also persisted despite many practical interventions in school physical education and other pedagogical sites (eg. McKenzie et al. 2004). A thread running through this narrative is that despite all of this research and related activity, we have yet to find the 'solution' to the 'problem' of girls and physical education.

In this paper, we offer a way of working with girls from an activist approach in order to better facilitate girls' engagement with physical education. We see girls' engagement with physical education as one crucial component in supporting them to lead physically active lives, and as pedagogues we see this as our first priority. While lifelong physical activity has been a commonplace feature in the discourse of school physical education over the last 40 year period, the evidence from surveys of adult participation suggests that physical educators have failed to achieve this objective, an objective for the most part they have set themselves (Kirk 2010). We argue that this remains a truly radical aspiration and that coming to value the physically active life is important to young people's willingness to become literate and critical lifelong participants in physical activity (Siedentop 1996).

In order to clarify our position we offer two caveats early in this paper that we will return to throughout. First, Wellard (2007) has cautioned that many projects with 'original good intentions' have inadvertently reproduced existing gender divisions. On the contrary, we believe that an activist approach that focuses specifically on girls' experiences provides essential spaces for them to identify, critique, and negotiate their self-identified barriers to valuing the physically active life. We see these forms of pedagogy as means of challenging rather than reproducing gender divisions. Second, we think that the proposals we will make for working with girls might equally be worth considering for working with boys. But we need to be clear that the basis of our proposals comes from empirical research with girls (some of which are centred in co-educational settings) and the studies we cite which form the basis of our proposals are also primarily from activist research with girls. We leave it to others to carry out research that could form the basis of work with boys in physical education.

We begin by offering a perspective on an activist approach as a means of breaking the reproductive cycle around girls in physical education. We do this in the spirit of Stenhouse's 
(1975) notion that a worthwhile pedagogical intervention should be thought of "not as an unqualified recommendation but rather as a provisional specification claiming no more than to be worth putting to the test of practice" (142). Next, we lay out the evidence that we believe suggests this approach is worth putting to the test of practice. First we introduce four critical elements shared by activist research studies: student-centred pedagogy; a focus on embodiment; inquiry-based physical education centred-in-action; and listening and responding to girls over time. We then draw on an example of a specific activist project to show how these four critical elements interconnect and interact in ways that support girls' engagement with physical education and participation in physical activity. Finally, we conclude with a discussion of a number of issues that we believe need to focus our work with girls in physical education over the coming decade if we are to break out of the same old story that is the dominant narrative surrounding the 'problem of girls in physical education', and create more hopeful narratives for girls' physical activity participation.

\section{An Activist Approach to Girls and Physical Education}

What might physical education research and practice come to look like [for girls] if more researchers viewed their responsibility not just as the generation of knowledge, but also as helping participants produce knowledge about themselves? (Enright and O’Sullivan 2012a, 51).

Collectively, feminist activist scholars working with adolescent girls in physical education settings have begun to answer Enright and O'Sullivan's long over-due question (Enright \& O’Sullivan 2012b, 2010a; Fisette 2011a; Fisette and Walton 2011; Hamzeh and Oliver 2012; Oliver and Lalik 2001, 2004a; Oliver, Hamzeh, and McCaughtry 2009). Activist scholars work from the belief that "valid knowledge is produced only in collaboration and in action" (Fine 2007, 613). A central theme in activist research is the "fundamental right to ask, investigate, dissent, and demand what could be" (Fine 2007, 613) ${ }^{\mathrm{i}}$. In working toward what could be Cook-Sather (2002) asks educators to embrace what Welch (1990) calls a 'feminist ethic of risk.' She describes this risk as a willingness to take small steps toward transforming oppressive practices even though complete change seems or is improbable (Cook-Sather 2002). In short, activist research becomes a means for changing the world, not merely studying it (Stanely 1990) and, as such, centres on "creating a legacy of inquiry, a process of change, and material resources to enable transformation" (Fine et al. 2004, 99).

We want to be clear about what we think is possible and desirable in this effort to 'change the world' for girls in physical education. We do not see this work as part of a grand 
narrative to overthrow the oppressive practices of masculine domination (Bourdieu 2001; Brown, 2006). We do not think it is appropriate for us to wait, as some scholars arguably imply (see Flintoff and Scraton 2006), until the gender order has been overthrown before girls can fully engage in physical education and lead active lives. Neither do we believe there is any single 'solution' to 'the problem' of girls and physical education. At the same time, we think that this work must seek to make more visible and transparent the 'naturalisation' of the gender order and thus how the small everyday practices of social interaction position girls and women as inferior to men and boys (Wright and King 1990). As such, an activist approach seeks to take small steps to improve the life situations of specific groups of girls in specific contexts. We ask the pragmatic questions, 'can we make the situation for girls better than it is currently?', 'what would be better?', and 'how might we go about this task?'

In light of these questions, our primary goal for physical education is that girls should come to 'value the physically active life' in so far as they become disposed to make routine physical activity possible for themselves and others around them (Siedentop 1996). Active lifestyles widely practiced are a radical goal since it has the potential to be transformative of women's place in the gender order. As Bourdieu $(2001,67)$ has noted, when we come to consider masculine domination, we must account not only for the social and economic circumstances in societies that favour men over women, but the embedding of these social structures in the body itself. He writes, "the masculinisation of the male body and the feminization of the female body, immense and in a sense interminable tasks....induce a somatization of the relations of domination, which is thus naturalized" (Bourdieu 2001, 5556). This somatization of the relations of domination is a matter of fundamental importance to physical educators, since it suggests working on and with the body must be part of any process of improving social equality (Wright and King, 1990; Vertinsky, 1992). In this context, Bourdieu states the

Intensive practice of a sport leads to a profound transformation of the subjective and objective experience of the body. It no longer exists only for others or ... for the mirror.... Instead of being a body for others it becomes a body for oneself; the passive body becomes an active and acting body. (Bourdieu 2001, 67)

Bourdieu notes that the power of masculine domination is such that women who play sport take many risks, including having their femininity and sexuality called into question. But these risks precisely make his point; the subversion of the gender order through an active and acting body provokes strong reactions in some men and women since it appears that the 'natural order of things' itself is being brought into question. 
Thus, as physical educators, we believe that a central aspiration for working with girls is that they develop a disposition to be physically active on a regular, sustained and sustainable basis, in whatever ways suit them (Vertinsky, 1992). Without an experiential base in physical activity, without work at the somatic level, we can have only limited impact on girls' understanding of the gender order and their place as women in a patriarchal society. This physical activity must be purposeful, to be sure, and it must be meaningful to girls in the moments of their engagement or else learning to value the physically active life is, we think, less likely (Whitehead 2010). The experience of purposeful physical activity also provides an essential basis for cultural critique, through which girls can learn to make more transparent the naturalisation of the gender order by identifying, naming, negotiating and overcoming barriers to their and their peers' physical activity participation (Oliver et al. 2009).

We recognize, however, progress in relation to this goal will not be the result of discovering some as yet unknown solution. It will instead proceed much as Rorty $(1999,86-$ 7) has described humanity's pursuit of moral progress, as less like finding the common essence, "something true and deep", that binds people together and "more like sewing together a very large, elaborate, polychrome quilt", to sew together "with a thousand little stitches" practices that eliminate, in our case, barriers to girls' valuing the physically active life.

For this particular paper, the claims we make are derived specifically from feminist activist researchers working with girls in physical education and physical activity settings in order to inspire change (e.g., Enright and O’Sullivan 2012a; Fisette 2011b; Oliver et al. 2009). What differentiates these scholars from the many others who have contributed to building a platform for understanding the significance of gender in physical education (eg. Azzarito 2010; Flintoff and Scraton 2006; Wright 1997) is that feminist activist scholars are always working toward transforming oppressive practices within the localized contexts in which they live and work - it is part of their research foci. Activist scholars continually aim to work within the structures that people live in order to change what can be changed. They engage in research with the intent to transform and change that which is (e.g., barriers to girls physical activity) rather than merely monitor that which is. Moreover, they make no claim that the girls they work with speak for anyone but themselves and their own barriers to valuing the physically active life.

Consistent with a pragmatist position (Dewey 1916; Rorty 1999; Vertinsky, 1992) that underpins and informs an activist approach, we consider theory to be in the service of practice rather than to be an end in itself. In the next section we introduce four critical 
elements that are emerging to form a patchwork of practice from an activist approach to working with girls in physical education. We offer these critical elements not as universal truths for all physical education programmes but, instead and consistent with Stenhouse (1975), as a provisional specification worth putting to the test of practice.

\section{Four critical elements of an activist approach}

We now have available to us a body of collective knowledge that illuminates what is possible for engaging girls in physical education when scholars go beyond the quest of finding 'the solution' by documenting 'what is', and begin instead studying 'what can be.' If we are actually to assist girls in the process of becoming physically active for a lifetime then we think teachers and researchers alike need to find better ways of supporting and nurturing girls' active engagement in physical education. We agree with Weiler (1988) who claims that it is important to recognize "the limits of what is possible to accomplish... and recognize the value and importance of doing what is possible" (153). In doing what is possible, we propose that there are four critical elements for a physical education agenda that facilitate girls' active engagement. These include: a) that teachers be student-centred in their pedagogical practices;

b) that teachers create spaces in their curriculum for girls to critically study their embodiment; c) that physical education be inquiry-based and centred in action; and d) that there is sustained listening and responding to girls over time. ${ }^{1}$ In this section, we will set out each of the critical elements derived from the collective knowledge of activist research programmes with girls and then in the section that follows offer an example of how these critical elements work together to facilitate girls' engagement with physical education and physical activity participation.

\section{Student-centred pedagogy}

'Ask girls more about their opinion on what they want to do' and 'start listening to girls and hearing what they want to do and give them a chance at different things and encourage them more.'...It's not that we don't like physical activity and sports; it's just that sometimes we don't like the kind of activities that people try to make us

\footnotetext{
${ }^{1}$ Throughout the section highlighting the four critical elements we are drawing on the collective body of activist scholars' lines of inquiry. Enright and O'Sullivan 2010a, 2010b, 2012a, 2012b in press; Fisette 2010, 2011a, 2011b; Fisette and Walton 2011; Hamzeh 2012; Hamzeh and Oliver 2012; Oliver 1999, 2001, 2010, 2013; Oliver and Lalik 2000, 2001, 2004; Oliver et al. 2009; Oliver and Hamzeh 2010; Oliver and Oesterreich 2013; Oliver and Oesterreich et al. 2013. We will only cite examples throughout the remainder of the paper as to not burden the reader with extensive and repeated citation.
} 
do... and sometimes we don't know what we like because we only get to try the same things all the time....If you want to get more girls active, you need to just listen to us and help us make our own clubs. (quoted in Enright and O'Sullivan 2012a, 261) In the final debriefing with the [youth] we asked them what they thought we did well. And one of them said we listened to their suggestions, another student said that everyone participated. And when we asked why we thought they all participated, she said it was because the games were fun, we got to make them, you change them to fit us and it was our choice. So we can see how important letting them have a say in what they do really played into this - Casey. (Oliver and Oesterreich 2012)

There now exists a strong and consistent body of research in physical education that demonstrates that when teachers are student-centred in their pedagogical practices they can and do facilitate girls' active and willing engagement in physical education (Ennis 1999; Enright and O'Sullivan 2012a; Fisette 2012; Oliver, Hamzeh, and McCaughtry 2009). These findings support the repeated recommendations of scholars in physical education that teachers need to be student-centred if they are going to better facilitate young people's engagement (e.g., Fitzgerald and Jobling 2004; Glasby and Macdonald 2004). The findings of these studies are also similar to other research on student-voice in the broader field of education (e.g., Cook-Sather 2009; Rudduck and McIntyre 2007; Schultz 2003). This broader research has demonstrated that school reform and curricular efforts informed by student voice increases students' involvement, ownership and consequent learning.

In this paper we define student-centredness as the ability and willingness of adults to listen to girls and respond to what they are hearing with respect to what facilitates and hinders their interest, motivation, learning, and ultimately their willingness to actively engage in physical education. Student-centredness does not mean doing everything kids want to do, nor does it mean hearing only to those who talk the loudest. Student-centredness means intentionally seeking student input over time from all girls with respect to how pedagogical practices are influencing their abilities and willingness to engage in physical education (e.g., Enright and O'Sullivan 2010a; Fisette and Walton 2011; Oliver and Oesterreich 2013).

This research shows that adults start from where girls are rather than where they are expected to be and in so doing they assist girls in learning how to lead physically active lives in and out of school in ways that are relevant and appropriate for girls themselves (Oliver et al. 2009). An important insight of this research is that adults work with girls' femininities rather than against them. Consequently, what is appropriate engagement for some girls may be in direct contrast to how we view conventional male-defined, physical activity 
participation (Thebege 1985). The activist research studies show that student-centredness does not assume there is only one way to be physically active, just like there is not only one type of girl, but rather it helps all girls learn that they can find activities that suit their individual needs and wants (Oliver et al. 2009).

\section{Creating spaces in the curriculum for girls to critically study their embodiment}

That's sick...Too muscular...I just think women should be feminine...not where you can see the muscle cause I think that's masculine-Alysa, age 13 (Oliver 1999, 239)

A second critical element for engaging adolescent girls in physical education involves teachers creating spaces in their curriculum for girls to critically study issues concerning their embodiment (e.g., Enright and O’Sullivan, in press; Goodyear, Casey and Kirk 2013; Hamzeh 2012; Oliver and Lalik 2001). These studies, as well as other's work on girls' embodiment (e.g., Azzarito and Solmon 2009; Hills 2006; Garrett 2004) provide strong evidence to suggest that purposeful physical activity is of central importance to girls' engagements in physical education, though it is not sufficient by itself. Offering girls the opportunities to explore their embodiment and how this relates to their physical activity enjoyment and participation, according to activist research, is central to physical education making sense to girls.

In several studies (Enright and O'Sullivan, in press; Fisette 2012; Oliver 2001; Oliver and Lalik 2004) girls were given opportunities to explore issues related to embodiment where they were able to name and critique aspects of physical culture that impact how they learn to think and feel about their bodies and the bodies of others and the ways that female and feminised bodies are constructed within the gender order. Given these opportunities girls also identified barriers to their physical education enjoyment and engagement as well as their physical activity participation. Consequently they were able to work with teachers to transform these barriers in order to create more appropriate environments (Fisette and Walton 2012; Oliver and Hamzeh 2010) and opportunities for physical activity participation (Enright and O'Sullivan 2012; Oliver et al. 2009). Creating opportunities for girls to critically study issues related to their embodiment was, in many of the activist studies, a precursor to girls actively participating in physical activity during physical education classes.

Creating opportunities for girls to critically examine issues of embodiment can take multiple forms. These ranged from engaging girls in magazine explorations or critiques (e.g., Oliver and Lalik 1999), to helping girls identify where they are receiving positive and negative messages about their bodies (Oliver and Lalik 2004), to exploring barriers to 
physical education engagement (Fisette 2012) and physical activity participation (Azzarito and Katzew 2010; Hamzeh and Oliver 2012), to exploring how social media influences their understandings of their bodies and the bodies of others (Fisette and Walton 2012), to scrapbooking, which allows girls to communicate how various forms of popular physical culture influence the ways they are thinking and feeling about their bodies (Enright and O'Sullivan, in press), to helping girls learn how to identify aspects of physical activity that bring them joy and friendship (Oliver 2013). These various opportunities facilitated girls learning more about what leading healthy, active lives entails. The pedagogical practices that lay behind these opportunities also helped teachers better understand the forces that influenced girls' interests, motivation, and learning within a physical education context that is, in girls' eyes, body-centred.

\section{Inquiry-based education centred-in-action}

It's the first time I've seen any purpose to PE. Sad but true... it's not nothing like before...It's more about trying to help us be smart active and confident to use stuff like gyms around where we live. Basically it's helping us be active more than once a week in class, we're helping ourselves be active actually, and PE [used not to] do that and it's also more about us and our lives, and that's first, but that's just not the case for PE that's in most school stuff. (quoted in Enright and O'Sullivan 2010a, 259-260) Collectively, the activist research studies show that inquiry-based education centred in action is a third critical element of working with adolescent girls in physical education (e.g., Enright and O'Sullivan 2012; Fisette and Walton 2011; Oliver and Hamzeh 2010). Inquiry, in and of itself, challenges the status quo of physical education because it requires fundamental questions to be asked about how physical education is practiced. Further, "inquiry changes relationships between students and teachers, as well as the way we view knowledge, who has that knowledge and how that knowledge must be used" (Oliver and Oesterreich et al. 2013, 3). In activist studies, teachers engaged girls in inquiry in order to help them better understand what facilitates and hinders their engagement in school physical education or physical activity outside of school as well as how they are learning to think and feel about their bodies. Teachers worked with girls in order to challenge and transform the barriers they identified and assisted them to develop strategies to increase their physical activity participation in ways that are meaningful to them.

However, in these studies, inquiry was not only what teachers have students do, but also it was what teachers do as a way of guiding their pedagogical decisions (Oliver and 
Oesterreich 2013). That is, within their curriculum design teachers embedded ways of continually inquiring into what facilitated and hindered girls' engagement, enjoyment, and learning in physical education and utilized this information in their planning and teaching. Collectively, activist research shows that girls used inquiry in order to come to understand issues of embodiment as well as issues of inequality that impacted their engagement in physical education. In activist studies students had ideas about how to initiate change in order to transform the barriers they experienced (e.g., Enright and O'Sullivan 2012; Fisette and Walton 2011; Oliver and Hamzeh 2010). In these studies, inquiry-based physical education is invariably oriented toward change - change that is directed at better facilitating girls' interest, motivation and learning in physical education. Enright and O'Sullivan (2012) document that sustained use of pedagogical approaches centred in inquiry and action "helped students to develop knowledge, skills, confidence and understandings that adult allies often struggle to teach students through conventional methods" (49).

Overall, when teachers incorporated student voice into their planning and instruction that was derived from inquiry, studies by activist scholars show that youth were not only more willing and interested in engaging in physical education, but they also were more willing and interested in taking responsibility for theirs and others learning because ultimately the ideas emerged from their interests and needs (e.g. Enright and O'Sullivan 2010). Inquiry-based education centred in action also creates opportunities for teachers to teach within their localized context, responding to the different needs of girls in different contexts while at the same time meeting state or national learning objectives (Oliver and Oesterreich 2013).

\section{Sustained listening and responding over time}

A fourth critical element is adults' willingness for sustained listening and responding to girls over time. Activist scholars argue there are no short cuts when it comes to understanding what facilitates and hinders girls' active engagement in physical education and participation in physical activity (Enright and O'Sullivan, in press; Oliver et al. 2009). Delgado (2006) writes, "the process of getting youth to voice their opinions may take a lot longer and require greater effort than most adults are willing to acknowledge...[and] any discussion of youth-led research is not complete without attention to the use of innovative research methods" (80-90). Nor are there any short cuts to creating physical education environments that are positive for girls (Oliver and Oesterreich et al. 2013). Activist research gets below the surface level barriers to girls' engagement in physical education and involves sustained listening and active and intentional responding over time. 
For activist researchers, long-term projects rather than short 'pop-in, pop-out' studies have been the norm (e.g., Oliver and Lalik 2000; Enright and O'Sullivan 2012). Activist researchers argue consistently that research methodologies that produce descriptive, surface level information (e.g., survey research, studies of short duration) fail to provide the types of knowledge needed to support girls' engagement in physical education and participation in physical activity. Enright and O'Sullivan (2012) state,

Students have years of learning what constitutes a teacher-pleasing response and in the beginning of our study many of our participants [e.g., girls] gave us the type of responses that they thought would please us. Most of the participants, for example, had over reported their physical activity participation in participation diaries they kept....[this] reminds us of the absolute necessity for triangulation and of spending significant time with our research participants. (45)

Activist research studies have shown convincingly that understanding alone is not sufficient however. Adults act responsively on their growing understanding of what girls need and in so doing support their interests, motivation and learning in physical education. Teachers work with girls to assist them in transforming barriers they identify as problematic to their physical activity participation, facilitating clear identification of what the real problems are and how these problems might be negotiated in order for girls to be more physically active (e.g., Enright and O'Sullivan 2012a; Hamzeh and Oliver 2012).

We think this is where so much of the physical education research with girls has failed. Outside of activist research, arguably research has not gotten to the place where transformation is possible. As Enright and O'Sullivan (2012a) report from their long-term activist research with girls

Establishing and investing in long-term relationships with student participants is necessary for all adult allies who wish to support student-voice-oriented initiatives. It will take time for students to trust that their voices are really being heard. Teachers need to be willing to invest this time, because developing meaningful collaborative relationships with students will take longer than telling students what to do. (263) We think that researchers who leave the scene before they fully understand what is going on with girls continue to report the same old findings about girls' disengagement in physical education.

Sustained listening and responding over time has similar implications for adult teachers working with girls in physical education settings. Activist research continually inquires into the forces that facilitate and hinder girls' interests, motivation and learning in 
physical education and then uses this information to guide pedagogical decisions (Enright and O’Sullivan 2012; Oliver and Oesterreich et al. 2013). Teachers who work within an activist approach seek student input across the duration of the year. It is not something done once at the beginning of the school year and left on the side-lines thereafter. Activist scholars have reported that it is through systematic inquiry coupled with their actively responding to the knowledge they gather that has facilitated girls' willingness to be open about what they need in a physical education setting to better meet their needs (Enright and O'Sullivan 2012b; Oliver et al. 2009). As Nicole, a participant in Oliver and Lalik's (2000) study stated,

When we first come in here we might talk about somethin' and then when we leave we might have been talkin' about something else. But like, when you come in on Thursday we can tell you were listenin' because you still remember. We can tell you thought about it. (108)

\section{The integration of critical elements: An example of what is possible for girls}

In this section we highlight one example to illustrate the power that integrating the four critical elements has on girls' engagement in physical education or physical activity. We use this example as a way to show how the different critical elements look in and of themselves but also how they work together to facilitate girls' engagement. Working in an Irish context in a three-year long participatory research project Enright and O'Sullivan (2010a; 2010b; 2012a; 2012b, in press) discuss the importance of negotiating the curriculum with girls. Their work is based on the ideas that students are primary stakeholders in their physical education experiences and should be recognized as co-constructors of knowledge and of action. They quote Australian curriculum expert Garth Boomer who wrote in 1992, "Negotiating the curriculum means deliberately planning to invite students to contribute to, and to modify, the educational program, so that they will have a real investment both in the learning journey and in the outcomes" (in Enright and O'Sullivan 2010, 204).

For the girls in Enright and O'Sullivan's (2010a) project, negotiating the curriculum involved "naming inequities; broadening horizons; and change agency" (208). Utilizing participatory action research methodologies as pedagogical tasks with which to engage girls in inquiry (Enright and O'Sullivan 2010b) they started with a six-week phase designed to assist the girls in naming physical education inequities. Here they worked to get to know the girls, what they valued and found interesting, and what they experienced as barriers to their physical education enjoyment and engagement by having the girls create task books. These books included a personal biography, a physical activity timeline and profile, and reflections 
on the girls' perceptions of physical education and alternative possibilities. What Enright learned in this phase was that the girls disengaged from physical education because the curriculum did not reflect in any way the girls' voices, did not provide girls with choices of activities, and was viewed by the girls as "stupid PE" (209).

Given where the girls were starting, unsure of what forms of physical activity were available, in the next phase Enright worked to broaden their horizons of what were possible physical education curricula. Drawing on the work of Maxine Greene, Enright hoped to assist the girls to imagine alternative physical education curricula. To do so she engaged the girls in a variety of "taster sessions" over a 10-week period of time. In these sessions the girls would try different forms of content taught by Enright. A debriefing section where the girls evaluated their experiences of the content in relation to their learning, interest, and future change followed each taster lesson. Each taster session built on what Enright was learning from the girls through the debriefings. What ultimately happened was that the girls and Enright held a "curriculum decision-making session" (210) where they collectively negotiated both aspects of the content as well as pedagogical processes. One of the things the girls wanted as a non-negotiable was that "we have to listen to the teachers because they are listening to us" (Enright \& O’Sullivan 2110a, 211).

Focusing on girls as change-agents, in the final phase of the research, Enright worked with the girls to "take responsibility for rethinking and changing their PE and physical activity experiences" (Enright and O'Sullivan 2010a, 211). During this phase the girls collaborated with Enright to co-construct an eight-week curriculum unit grounded in the girls' previous inquiry-based work. Collectively they acted together to design a unit that would assist girls in trying "new things in PE that will help us to like being active and help us to be active more and it will be good fun" (Enright and O'Sullivan 2010a, 212). Enright's findings revealed that the girls increased involvement in the curriculum decision-making impacted their engagement in physical education in four specific ways. These included the girls' increased participation and being prepared (dressed out) to participate, an increase in learning and taking responsibility for theirs and others learning, increased accountability for their roles and responsibilities within the class, and an awareness in physical activity possibilities in their communities coupled with an increase in self-confidence to pursue those possibilities.

Clear in Enright's study are the four critical elements of student-centred pedagogy, opportunities to study issues of embodiment, inquiry-based learning centred in action and sustained listening and responding. The value in using inquiry centred in action as a way to 
engage girls in physical education was reflected not only in the girls actions, but also in their words, “'we're more in charge;' 'it makes you think;' 'we can change things, make a difference' and; 'it was just good fun'” (Enright and O'Sullivan 2012, 44). Her example illustrates that through the interconnection of these four critical elements girls not only contributed to their physical activity engagement but did so in ways that they found meaningful and relevant and appreciated being valued for what they could do to improve their physical education experience. While we highlight only one example, works from other activist scholars in different cultural contexts, with different types of girls shows how the four critical elements interact in their work with girls.

\section{Discussion}

We think there are a least three issues arising from what we have presented in this paper thus far that require further consideration and discussion. We see this discussion as part of a process of clarifying how we work with girls in physical education in order to make the situation for girls better than it is currently. These issues are: no more of the same old story, scaling-up activist research, and the development of a pedagogical model for girl-friendly physical education.

\section{No more of the same old story}

We argued in the introduction to this paper that some of the research on girls and physical education covers the same ground again and again and comes up with the same findings and recommendations in the quest for 'the solution' to the 'problem' of girls and physical education. We have offered an activist approach as one possible means of breaking this cycle by working with girls to make more transparent the naturalisation of masculine domination with the gender order (Bourdieu, 2001). But we do so with two points to note. The first is that we understand circumstances change constantly and create new challenges for working with girls, in terms of economics, the environment, culture and education systems. It will be important to be alert to these changing circumstances and their implications for working with girls in physical education, and we need research to be attuned to this agenda. But, as we will propose below, research needs to be in service of practice and integral to the process of making the situation for girls better than it is currently.

This first point informs the second we wish to raise around the dominant narrative about girls and physical education, which is a need for critical consensus on what has to be done and how we do it. We are not suggesting that an activist approach is THE answer to the issue of girls and physical education; the pragmatist underpinnings of an activist approach 
disallow this possibility. We ARE suggesting however that this approach should be taken seriously by everyone interested in improving the situation for girls, seriously enough to be tested in practice. We say 'critical consensus' because we are not suggesting there is no place for criticism and dissent, indeed, quite the opposite. But we are proposing that there has been sufficient accumulation of evidence over many years for a level of consensus to be reached. We understand too that consensus does not simply happen and that the media in particular need to be educated not to reproduce the same old story in the same old reductionist and simplistic terms. This task requires strenuous and unremitting effort around consensus on what needs to be done and how.

\section{Scaling-up activist research}

A second discussion point is how we might go about scaling-up activist research. To date, individuals or small teams of researchers working in local and specific contexts have carried out most of the studies we have described as activist. The point for discussion is how an activist approach characterised by the four critical elements we have highlighted earlier might become widespread practice and at the same time maintain the integrity of this approach. Part of the challenge to maintaining the integrity of this approach is being responsive to specific needs of girls in local contexts. This challenge is, we suggest, common to much educational research that has discovered the need to balance between prescription on the one hand and freedom on the other, and for researchers and teachers (for example) to work collaboratively in genuine partnerships (see Kirk and Macdonald 2001). The ways in which teacher continuing professional development is conducted will be a significant factor in this scaling-up process. Armour and Yelling (2007) have shown that the off-site, one-off, 'training' of teachers through a 'cascade' of new ideas does not result in effective changes to teachers' practice. How might we go about this scaling-up process mindful of these issues of integrity of an activist approach in relation to local contexts of implementation, the continuing professional development of teachers, and the formation of genuine collaborative partnerships among researchers, teachers and others?

The development of a pedagogical model for working with girls in physical education

One way to manage the various challenges of scaling-up activist research may be to move towards the development of a pedagogical model for working with girls in physical education. Kirk (2013) and Casey (2013) have developed a case for a 'models-based' approach to physical education building on the work of Metzler (2005) on 'instructional models' and Jewett et al. (1995) on 'curriculum models'. A pedagogical model is a 'design specification' for developing programmes in local contexts. This design specification 
includes, among other things (see Haerens et al. 2011), the critical elements that make the model distinctive, a set of key learning outcomes and a key theme. Crucially, the model becomes what Metzler (2005) calls the 'organising centre' for physical education and learning outcomes are tightly aligned with subject matter and teaching strategies.

An aspiration of this models-based approach is to assist researchers and teachers to manage the tensions created by the scaling-up process, so that the innovative approach can maintain some level of acceptable integrity while at the same time providing space to make adaptations to fit the local context of implementation. Our point for discussion here is how we might pursue the development of a pedagogical model for working with girls in physical education building on the four critical elements that feature within activist research (Oliver and Oesterreich et al. 2013; Oliver and Oesterreich 2013). Would this development allows us to maintain the integrity of an activist approach while at the same time allow space for local adaptation?

\section{Conclusion}

In this paper we have offered an activist approach to work with girls in physical education as one possible means of breaking what we have characterised as a reproductive cycle that has done little to improve the current situation for girls. We have done so in the basis of Stenhouse's (1975) notion that such an approach is not 'the solution' to the 'problem' of girls in physical education, but nevertheless worthy of testing in practice. Overviewing the findings of a growing body of activist studies in physical education, we identified four critical elements that we believe need to be present in order to assist girls to identify, name and negotiate barriers to their engagements with physical education and their participation in physically active lifestyles. In our discussion based on this work, we argue for the need for a consensus around improving the current situation of girls in physical education, for a scaling-up of this activist work as it is tested in practice, and for the coincidental development of a pedagogical model for working with girls in physical education.

We believe there is no single quick fix solution to improving the situation of girls in physical education. But at the same time we are, on the basis of our analysis, calling for a shift in focus for research and development work in this field. As many others have noted for far too long in the research literature, the current situation is unacceptable and untenable. We invite all researchers, teachers, policy-makers and significant others to critically engage in the process of breaking the reproductive cycle of research and advocacy so that we develop a new agenda for girls in physical education. 
References

Armour, K.M. and M. Yelling 2007. "Effective Professional Development for Physical Education Teachers: The Role of Informal, Collaborative Learning." Journal of Teaching in Physical Education 26, 177-200.

Azzarito, L. M., and A. Katzew. 2010. "Performing Identities in Physical Education: (En)gendering Fluid Selves.” Research Quarterly for Exercise and Sport 81 (1): 25-37.

Azzarito, L.M., and M.A. Solmon. 2006. "A Poststructural Analysis of High School Students' Gendered and Racialized Bodily Meanings." Journal of Teaching in Physical Education 25 (1): 75-98.

Azzarito, L., and M. A. Solmon. 2009. “An Investigation of Students' Embodied Discourses in Physical Education: A Gendered Project." Journal of Teaching in Physical Education 28 (2): 173-191.

Azzarito, L., M. A. Solmon, and L. Harrison. 2006. ““...If I Had a Choice, I Would...’ a Feminist Post-structural Perspective on Girls in Physical Education.” Research Quarterly for Exercise and Sport 77 (2): 222-239.

Barr-Anderson, D. J., D. Neumark-Sztainer, L. Lytle, K. H. Schmitz, D. S. Ward, T. L. Conway, C. Pratt, C. D. Baggett, and R. R. Pate. 2008. "But I Like PE: Factors Associated With Enjoyment of Physical Education Class in Middle School Girls.” Research Quarterly for Exercise and Sport 79 (1): 18-27.

Biddle, S. J. H., S. H. Whitehead, T. M. O’Donovan, and M. E. Nevill. 2005. “Correlates of Participation in Physical Activity for Adolescent Girls: A Systematic Literature Review and Update." Journal of Physical Activity and Health 2: 423-434.

Birchley, Emma. 2012. "PE 'Puts Half Of Girls Off Exercise For Life."' Sky News. http://news.sky.com/story/14720/pe-puts-half-of-girls-off-exercise-for-life

Bourdieu, Pierre. 2001. Masculine Domination. Cambridge: Polity.

Brown, D. (2006) 'Pierre Bourdieu's ' 'Masculine Domination' Thesis and the Gendered Body in Sport and Physical Culture." Sociology of Sport Journal, 23: 162-188. 
Campbell, Denis. 2012. "Ugly Games Kit Turns Girls Off PE." The Guardian. http://www.guardian.co.uk/uk/2005/jan/16/health.schools

Casey, A. 2012. Models-based Practice: Great White Hope or White Elephant? Physical Education and Sport Pedagogy. doi:10.1080/17408989.2012.726977.

Cook-Sather, A. 2002. “Authorizing Students' Perspectives: Toward Trust, Dialogue, and Change in Education." Educational Researcher 3 (4): 3-14.

Cook-Sather, A. 2009a. “'I Am Not Afraid to Listen': Prospective Teachers Learning from Students." Theory Into Practice 48 (3): 176-183.

Delgado, Melvin. 2006. Designs and Methods for Youth-Led Research. London: Sage.

Dewey, John. 1916. Democracy and Education. New York: Free Press.

Ennis, C. D. 1999. “Creating Culturally Relevant Curriculum for Disengaged Girls.” Sport, Education and Society 4 (1): 31-49.

Ennis, C. D. 2000. "Canaries in the Coal Mine: Responding to Disengaged Students Using Theme-based Curricula." Quest 52 (2): 119-130.

Enright, E., and M. O’Sullivan. 2010a. “'Can I Do It in My Pyjamas?' Negotiating a Physical Education Curriculum with Teenage Girls.” European Physical Education Review 16 (3): 203-222.

Enright, Elimear, and Mary O’Sullivan. 2010b. “'Carving a Few Order of Experience’ with Young People in Physical Education: Participatory Action Research as a Pedagogy of Possibility." In Young people's voices in physical education and youth sport, edited by Mary O’Sullivan and Ann MacPhail, 163-185. London: Routledge.

Enright, E., and M. O’Sullivan. 2012a. "Physical Education 'In All Sorts of Corners': Student Activists Transgressing Formal Physical Education Curricular Boundaries.” Research Quarterly for Exercise and Sport 83 (2): 255-267.

Enright, E., and M. O’Sullivan. 2012b. “Producing Different Knowledge and Producing Knowledge Differently': Rethinking Physical Education Research and Practice Through Participatory Visual Methods.” Sport, Education and Society 17 (1): 35-55. 
Faulkner, Katherine. 2012. "Grubby Changing Rooms and Embarrassment at Getting Sweaty in Front of Boys Mean PE Lessons are Putting Girls Off Exercise for Life.” Mail Online. http://www.dailymail.co.uk/health/article-2138182/Grubby-changing-rooms-embarrassmentgetting-sweaty-boys-mean-PE-lessons-putting-girls-exercise-life.html

Fine, Michelle. 2007. “Feminist Designs for Difference.” In Handbook of feminist research: Theory and praxis, edited by Sharlene Nagy Hesse-Biber, 613-620. Thousand Oaks: Sage.

Fine, Michelle, Maria Elena Torre, Kathy Boudin, Iris Bowen, Judith Clark, Donna Hylton, Migdalia Martinez, Melissa Rivera, Rosemarie Roberts, Pamela Smart, and Debora Upegui. 2004. "Participatory Action Research: From Within and Beyond Prison Bars. In Working method: Research and social justice, edited by Lois Weis and Michelle Fine, 95-120. New York: Routledge.

Fisette, J. L. 2011. "Exploring How Girls Navigate Their Embodied Identities in Physical Education.” Physical Education and Sport Pedagogy 16 (2): 179-196.

Fisette, J. L. 2011. 'Negotiating Power within High School Girls' Exploratory Projects in Physical Education." Women in Sport and Physical Activity Journal 20 (1): 73-90.

Fisette, J. L. 2012. “'Are You Listening?’: Adolescent Girls Voice How They Negotiate Selfidentified Barriers to Their Success and Survival in Physical Education." Physical Education and Sport Pedagogy 18 (2): 184-203. doi: 10.1080/17408989.2011.649724.

Fisette, J. L., and T. A. Walton. 2011. “If You Really Knew Me'...I Am Empowered Through Action.” Sport, Education and Society 1-22. doi:10.1080/13573322.2011.643297.

Fitzgerald, Hayley, and Anne Joblin. 2004. Student-centered Research: Working With Disabled Students. In Critical inquiry and problem-solving in physical education, edited by Jan Wright, Lisette Burrows, and Doune Macdonald, 74-92. London: Routledge. 
Flintoff, Anne, and Sheila Scraton. 2006. "Girls and Physical Education." In The handbook of physical education, edited by David Kirk, Doune Macdonald, and Mary O'Sullivan, 767-783. London: Sage.

Garner, Richard. 2012. "'Unfeminine' School Sports Leave Girls on the Sidelines." The Independent. http://www.independent.co.uk/news/education/education-news/unfeminineschool-sports-leave-girls-on-the-sidelines-7704402.html

Garrett, Robyne. 2004. "Gendered Bodies and Physical Identities." In Body knowledge and control: Studies in the sociology of physical education and health, edited by John Evans, Brian Davies, and Jan Wright, 140-156. London: Routledge.

Garrett, R. 2004. "Negotiating a Physical Identity: Girls, Bodies and Physical Education." Sport, Education and Society 9 (2): 223-237.

Glasby, Trish, and Doune Macdonald. 2004. "Negotiating the Curriculum: Challenging the Social Relationships in Teaching." In Critical inquiry and problem-solving in physical education, edited by Jan Wright, Doune Macdonald, and Lisette Burrows, 133-144. London: Routledge.

Goodyear, Victoria, Ashley Casey, and David Kirk. 2013. "Slights, Cameras, Inaction: Using Flip Cameras in Cooperative Learning to Explore Girls' (Dis)Engagment in Physical Education." In Pedagogies, physical culture, and visual methods, edited by Laura Azzarito and David Kirk, 47-61. New York: Routledge.

Gray, John. 2002. False Dawn: The delusions of global capitalism. London: Granta.

Haerens, L., D. Kirk, G. Cardon, and I. Bourdeauhuji. 2011. "The Development of a Pedagogical Model for Health-based Physical Education.” Quest 63, 321-338.

Hamzeh, Manal. 2012. Pedagogies of Deveiling: Muslim Girls \& the Hijab Discourse. North Carolina: Information Age Publishing, Inc.

Hamzeh, M., and K. L. Oliver. 2012. “'Because I am Muslim, I Cannot Wear a Swimsuit”: Muslim Girls Negotiate Participation Opportunities for Physical Activity.” Research Quarterly for Exercise and Sport 83 (2): 330-339. 
Hills, A. 2006. "Playing the Field(s): An Exploration of Change, Conformity and Conflict in Girls' Understandings of Gendered Physicality in Physical Education.” Gender and Education 18 (5): 539-556.

Hughes, Jane. 2012. "Girls and Sport: Schools Urged to Make PE More Attractive to Girls". BBC News. http://www.bbc.co.uk/news/health-17873519

Institute for Youth Sport (IYS). 2001. Towards 'Girl-friendly' Physical Education. Final Report, Nike/ YST 'Girls in Sport' Partnership Project. Leicestershire: Loughborough University.

Jewett, Ann, Linda Bain, and Catherine Ennis. 1995. The Curriculum Process in Physical Education. 2nd ed. Madison: Brown.

Kirk, David. 2010. Physical Education Futures. London: Routledge.

Kirk, D. 2013. "Educational Value and Models-Based Practice in Physical Education." Educational Philosophy and Theory. doi:10.1080/00131857.2013.785352.

Kirk, D., and D. Macdonald. 2001. "Teacher Voice and Ownership of Curriculum Change.” Journal of Curriculum Studies 33 (5): 551-567.

MacPhail, A., D. Kirk, and D. Eley. 2003. "Listening to Young People's Voices: Youth Sport Leaders' Advice on Facilitating Participation in Sport." European Physical Education Review 9 (1): $57-74$.

Metzler, Michael. W. 2005. Instructional Models for Physical Education. 2nd ed. Scottsdale: Holcomb Hathaway.

National Health Service (NHS). 2012. PE Lessons 'Put Girls Off Exercise.' http://www.nhs.uk/news/2012/05may/Pages/girls-put-off-exercise-school-sport.aspx

O'Donovan, T. M., and T. A. Kay. 2005. "Focus on Girls in Sport." British Journal of Teaching Physical Education 36 (1): 29-31.

O’Sullivan, Mary, and Ann MacPhail, eds. 2010. Young People's Voices in Physical Education and Youth Sport. London: Routledge. 
Oliver, Kim. 2010. "The Body, Physical Activity and Inequity: Learning to Listen With Girls Through Action." In Young people's voices in physical education and youth sport, edited by Mary O’Sullivan and Ann MacPhail, 31-48. London: Routledge.

Oliver, Kim L. 2013. "Beyond Words: The Visual as a Form of Student-centered Inquiry of the Body and Physical Activity." In Physical culture, pedagogies and visual methods, edited by Laura Azzarito and David Kirk, 15-29. New York: Routledge.

Oliver, Kim. L. with Jarrod Archuleta, Casey Blazer, Kandy De La Cruz, Daniel Martinez, Jenn McConnell, Maggee Osta, Lacie Parks, and Rinalldo Robinson. "Student-centered and Inquiry-based Physical Education Teacher Education.” Paper presented at the American Alliance of Health, Physical Education, Recreation and Dance Conference, Indianapolis, March 2010.

Oliver, K. L., and M. Hamzeh. 2010. ““The Boys Won't Let Us Play': $5^{\text {th }}$ Grade Mestizas Publicly Challenge Physical Activity Discourse at School. Research Quarterly for Exercise and Sport 81 (1): 39-51.

Oliver, K. L., M. Hamzeh, and N. McCaughtry. 2009. “"Girly Girls Can Play Games/Las Niñas Pueden Jugar Tambien': Co-creating a Curriculum of Possibilities With $5^{\text {th }}$ Grade Girls.” Journal of Teaching in Physical Education 28 (1): 90-110.

Oliver, K. L., and R. Lalik. 2001. "The Body as Curriculum: Learning with Adolescent Girls." The Journal of Curriculum Studies 33 (3): 303-333.

Oliver, K. L., and R. Lalik. 2004a. "Critical Inquiry on the Body in Girls' Physical Education Classes: A Critical Poststructural Analysis." Journal of Teaching in Physical Education 23 (2): 162-195.

Oliver, K. L., and R. Lalik. 2004b. “'The Beauty Walk, This Ain’t My Topic’: Learning About Critical Inquiry with Adolescent Girls.” The Journal of Curriculum Studies 36 (5): $555-586$.

Oliver, Kim L., and Heather A. Oesterreich. "Student-Centered Inquiry as Curriculum as a Model for Physical Education Teacher Education." Paper presented at the American Education Research Association, Vancouver, April 2012. 
Oliver, K. L., and H. A. Oesterreich. 2013. "Student-centred Inquiry as Curriculum as a Model for Field-based Teacher Education.” Journal of Curriculum Studies 43 (3): 394-417. Oliver, K. L. 1999. “Adolescent Girls’ Body-narratives: Learning to Desire and Create a 'Fashionable' Image.” Teachers College Record 101 (2): 220-246.

Oliver, Kim L. and H. A. Oesterreich with R. Aranda, J. Archuleta, C. Blazer, K. De La Cruz, D. Martinez, J. McConnell, M. Osta, L. Parks, and R. Robinson. 2013. “"The Sweetness of Struggle': Innovation in PETE Through Student-centred Inquiry as Curriculum in a Physical Education Methods Course.” Physical Education and Sport Pedagogy. doi: 10.1080/17408989.2013.803527.

Rorty, Richard. 1999. Philosophy and Social Hope. London: Penguin.

Rudduck, Jean, and Donald McIntyre. 2007. Improving Learning Through Consulting Pupils. London: Routledge.

Schultz, Katherine. 2003. Listening: A Framework for Teaching Across Differences. New York: Teachers College Press.

Siedentop, D. 1996. "Valuing the Physically Active Life: Contemporary and Future Directions." Quest 48, 266-274.

Stenhouse, Lawrence. 1975. An Introduction to Curriculum Research and Development. London: Heinemann.

Theberge, N. 1985. "Towards a Feminist Alternative to Sport as the Male Preserve." Quest 37, 193-202.

McKenzie, T. L., J. F. Sallis, J. J. Prochaska, T. L. Conway, S. J. Marshall, and P. Rosenguard. 2004. "Evaluation of a Two-Year Middle-School Physical Education Intervention: M-SPAN." Medicine \& Science in Sports \& Exercise 36 (8) 1382-1388.

Vertinsky, P. A. 1992. "Reclaiming Space, Revisioning the Body: The Quest for Gendersensitive Physical Education." Quest 44 (3): 373-396.

Walker, Harriet. 2012. "I Blame the Psychotic Gym Teachers.” The Independent. http://www.independent.co.uk/voices/commentators/harriet-walker-i-blame-the-psychoticgym-teachers-7704401.html 
Weiler, Kathleen. 1988. Women Teaching for Change. Gender, Class and Power. South Hadley: Bergin \& Garvey.

Taylor, W. C., A. K. Yancey, J. Leslie, N. G. Murray, S. S. Cummings, S. A. Sharkey, C. Wert, J. James, O. Miles, and W. J. McCarthy. 2000. "Physical Activity Among African American and Latino Middle School Girls: Consistent Beliefs, Expectations, and Experiences Across Two Sites.” Women \& Health 30 (2) 67-82. doi: 10.1300/J013v30n02_05

Wellard, I. 2007, ed. Rethinking Gender and Youth Sport. London: Routledge.

Whitehead, Margaret. 2010. Physical Literacy: Throughout the Lifecourse. London: Routledge.

Women's Sport and Fitness Foundation (WSFF). 2012. Changing the Game for Girls. http://www.wsff.org.uk/system/1/assets/files/000/000/285/285/f4894dccf/original/Changing _ The_Game_For_Girls_Final.pdf

Wright, J. 1996. "Mapping the Discourses in Physical Education." Journal of Curriculum Studies 28 (3): 331-351.

Wright, J. 1997. "The Construction of Gendered Contexts in Single Sex and Co-educational Physical Education Lessons." Sport, Education and Society 2 (1): 55-72.

Wright, J. and King, R.C. 1990. ““I Say What I Mean,” Said Alice: An Analysis of Gendered Discourse in Physical Education.” Journal of Teaching in Physical Education 10, 210-225.

\footnotetext{
'This differs from action research that centres on studying one's own practice with the intent to become a better practitioner.
} 